\title{
Study on Nitrogen Levels and Varieties on Yield Contributing Characters, Quality and Economics of Mustard (Brassica juncea Curzen and Cross.) Varieties under Late Sown Condition
}

\author{
Nikhil Raghuvanshi ${ }^{*}$, Vikash Kumar ${ }^{2}$ and Jai Dev ${ }^{3}$ \\ ${ }^{1}$ Department of Agronomy, Narendra Deva University of Agriculture and Technology, \\ Kumargaj, Faizabad (Uttar Pradesh), India \\ ${ }^{2}$ Department of Agronomy, Banaras Hindu University, \\ Varanasi, (Uttar Pradesh), India \\ ${ }^{3}$ Professor of Agronomy, Narendra Deva University of Agriculture and Technology, \\ Kumargaj, Faizabad (Uttar Pradesh), India
}

*Corresponding author

\begin{tabular}{|c|c|}
\hline & A B S T R A C T \\
\hline $\begin{array}{l}\text { Nitrogen, Yield } \\
\text { attributes, Seed, } \\
\text { Stover, Quality, } \\
\text { Economics } \\
\text { Mustard, NDR- } \\
8501 \text {, Vardan, } \\
\text { Maya }\end{array}$ & \multirow{3}{*}{$\begin{array}{l}\text { A field experiment was conducted during the winter ( } \mathrm{rabi} \text { ) season of } 2015-16 \text { to Study on } \\
\text { the nitrogen levels and varieties on yield contributing characters, quality and Economics of } \\
\text { mustard (Brassica juncea Curzen and Cross.) varieties under late sown condition at Main } \\
\text { Agronomy Research Station, Narendra Deva University of Agriculture and Technology, } \\
\text { Faizabad (Uttar Pradesh). Testing the experiment near alkaline in } \mathrm{pH} \text {, low EC, Organic } \\
\text { carbon and available N, medium in available P and medium available K. The experiment } \\
\text { was laid out in Factorial randomized block design with five Nitrogen levels viz. 0, 40, } \\
60,120 \text { and } 160 \mathrm{~kg} \mathrm{ha}^{-1} \text { and three varieties Vardan, NDRI- } 8501 \text { and Maya with three } \\
\text { replication. The plants without treatments were served as control. Seed yield and its } \\
\text { components were significantly increased in all the treatments over control. The maximum } \\
\text { grain yield was noted with } 120 \mathrm{~kg} \text { Nitrogen and variety NDRI- } 8501 \text {. An increase in the } \\
\text { grain yield at the abovementioned treatments was may be due to the increase of number of } \\
\text { siliqua, length of siliqua, number of seed siliqua }{ }^{-1} \text {, test weight. Under different treatment } \\
\text { combinations (interactions) the maximum net return of Rs. } 54807 \text { ha }^{-1} \text { and B:C ratio (2.67) } \\
\text { was obtained from } 120 \mathrm{~kg} \text { ha- } 1 \text { and NDRI- } 8501 \text { combination. }\end{array}$} \\
\hline Article Info & \\
\hline $\begin{array}{l}\text { Accepted: } \\
\text { 24 June } 2018 \\
\text { Available Online: } \\
\text { 10 July } 2018\end{array}$ & \\
\hline
\end{tabular}

\section{Introduction}

Crop production largely depends on cultivation of high yielding varieties and need based application of nutrients. Nitrogen $(\mathrm{N})$ is the most important nutrient, and being a constituent of protoplasm and protein, it is involved in several metabolic processes that strongly influence growth, productivity and quality of crops (Reddy and Reddy 1998, Kumar et al., 2000). The $\mathrm{N}$ fertilizer application accounts for significant crop production cost. Rapeseed-mustard group of crops have relatively high demand for $\mathrm{N}$ than 
many other crops owing to larger $\mathrm{N}$ content in seeds and plant tissues (Laine et al., 1993, Malagoli et al., 2005). Yield increases in Indian mustard at various locations in India have been reported with application of $\mathrm{N}$ as high as $150 \mathrm{~kg} \mathrm{ha}^{-1}$ or more (Tomar et al., 1997, Deekshutulu et al., 1998, Singh et al., 2010). A significant part of the unused $\mathrm{N}$ is lost to environment causing pollution and contamination of water bodies (Malagoli et al., 2005) or gets converted to greenhouse gases such as oxides of N. Furthermore, N efficiency decreases with increase in $\mathrm{N}$ application (Chamoro et al., 2002). Increasing $\mathrm{N}$ application also reduces oil content (Dubey et al., 1994, Singh and Singh 2005 and Singh et al., 2008). Since $\mathrm{N}$ fertilizers are costly, poor nitrogen use efficiency is of great concern and therefore, attempts are needed to improve the contribution of applied $\mathrm{N}$ to production of grain and this approach will reduce the environmental and production costs in agriculture. Almost all investigations showed that nitrogen fertilizers gave substantial seed yield increase even in diverse and contradicting conditions (Siadat et al., 2010). However, nitrogen fertilizer's requirements can differ very much according to soil type, climate, management practice, timing of nitrogen application, cultivars, etc Bani-saeedi (2001). The quality of oil primarily depends on its fatty acid composition. Traditional cultivars of rapeseedmustard contain high proportion of long chain fatty acids such as eicosenoic and erucic acid (more than 45\%) and low proportion of oleic acid (15-20\%) in oil. These long chain fatty acids are reported to cause thickening of arteries and increase blood cholesterol leading to heart ailments in human beings (Zhao et al., 1993).

Differences in $\mathrm{N}$ concentration in various plant parts of oilseed rape (Brassica napusL.) suggest that $\mathrm{N}$ uptake and distribution is an inherited character (Grami and La Croix
1977). Spring oilseed rape cultivars producing lowest yields at lowest level of $\mathrm{N}$ application generally responded more markedly to increased $\mathrm{N}$ application rates than cultivars with higher yield at high $\mathrm{N}$ application (Yau and Thurling, 1987a, b). Since $\mathrm{N}$ fertilizers are costly, poor NUE is of great concern and therefore, attempts are needed to improve the contribution of applied $\mathrm{N}$ to production of grain and this approach will reduce the environmental and production costs in agriculture but such information is not available for Eastern Uttar Pradesh mustard. Considering that the information on yield and quality of mustard with respect to nitrogen and varieties under late sown condition is still not available in this region, the present study aims to generate more information concerning the Study on the nitrogen levels and varieties on yield contributing characters, quality and Economics of mustard (Brassica juncea Curzen and Cross.) varieties under late sown condition of Uttar Pradesh, India.

\section{Materials and Methods}

The field experiment was carried out during winter season of 2015- 16 at Main Agronomy Research Station, Narendra Deva University of Agricultural and Technology, Faizabad (Uttar Pradesh) during the rabi season of 2015-16. The farm is located at $42 \mathrm{~km}$ away from Faizabad city on Faizabad- Raebareily road at $26.47^{\circ} \mathrm{N}$ latitude, $82.12^{\circ} \mathrm{E}$ longitude and an altitude of about 113 metres above the mean sea level. Faizabad (Uttar Pradesh) is characterized by sub-tropical, semi-arid type of climate with hot and dry summer during April to June followed by hot and humid period during July to September and cold winter during December and January. The mean maximum and minimum temperatures show considerable variations during different months of the year. Temperature often exceeds $42^{\circ} \mathrm{C}$ during summer and sometimes touches above $45^{\circ} \mathrm{C}$ with dry spells during 
May and June. Minimum temperature falls below 5oC with some frosty spells during the winter months of December and January. The meteorological data recorded during standard meteorological weeks (SMWs) of the crop growing season (rabi2015-16) obtained from meteorological observatory of the university, which is located at a distance of 900 meters from the experimental site. The mean temperature recorded during first week of November (45th SMW) 2015 to fourth week of March (12th SMW) 2016 ranged between $5.2 \mathrm{oC}$ to $33.4 \mathrm{oC}$. The mean relative humidity varied from 42.7 to 78.8 per cent during crop growth period. A rainfall of $4.8 \mathrm{~mm}$ was recorded in the month of March, 2016.The evaporation rate varied from $1.7 \mathrm{~mm}$ to 5.8 in the month of November and March, respectively. Daily mean sunshine hours ranged from 2.7 hours in 3 rd $\mathrm{SMW}$ to 8.1 hours in 9th SMW. The soil of the experimental field belongs to the major group of Indo- Gangetic which is silt loam up to 15 cm depth (Table 1).

\section{Experimental details of the research field}

The cropping sequence of the experimental field for the preceding 5 years was rice, blackgram and sorghum followed by mustard, chickpea wheat. The experiment was laid out in Randomized Block Design (RBD), keeping the three varieties viz. vardan, NDRI - 8501 and maya were laid out with five nitrogen levels $0,40,80,120$ and $160 \mathrm{~kg} \mathrm{ha}{ }^{-}$ ${ }^{1}$ respectively, with thee replication. The crop was fertilized with a uniform dose of phosphorus and potassium at the rate of $60 \mathrm{~kg}$ and $40 \mathrm{~kg} \mathrm{ha}^{-1}$, respectively. Nitrogen was applied as per treatments Urea, DAP and Murate of potash were used as the source of nitrogen, phosphorus and potassium. The full dose of phosphorus and potassium and half dose of nitrogen was applied as basal dose and remaining half dose of nitrogen was given in two equal splits as top dressing each after first and second irrigations. Two irrigations were given in the mustard crop. First irrigation was done at (25 DAS) and second irrigation was done at siliqua formation stage (55 DAS) of the crop. Land preparation was done after harvesting of kharif crop. One ploughing was done by disc plough followed by two ploughings by tractor drawn cultivator and planking was done invariably after each ploughing to get the fine seed bed. Layout was done carefully as per technical programme of the experiment. Thinning was done in two phases. In the first phase dense emerging seedlings were uprooted after 10 days of sowing. Second phase of thinning was completed 25 DAS by maintaining plant to plant and row to row distance as $45 \mathrm{~cm}$ and 15 $\mathrm{cm}$, respectively. Mustard seeds were sown in lines at the distance of $45 \mathrm{~cm}$ and $15 \mathrm{~cm}$ plant to plant with the help of seed drill. The seed rate was used $5 \mathrm{~kg} \mathrm{ha}{ }^{-1}$. The crop was harvested at complete maturity as judged by visual observation. The border rows from both the sides and $45 \mathrm{~cm}$ from each side width wise were harvested first and kept aside. Thereafter, crop of each net plot was harvested separately and brought to threshing floor after proper tagging. The produce of net plot was weighed individually and recorded before threshing. Threshing was done by wooden sticks and seed weight was recorded for net plot after winnowing the produce. To obtain stover yield the seed weight was subtracted from total biomass recorded from each plot.

\section{Estimation of traits}

At maturity, ten random samples were hand harvested from each experimental unit and the following parameters were determined: plant height $(\mathrm{cm})$, number of seeds siliqua ${ }^{-1}$, leangth of siliqua $(\mathrm{cm})$ and number of siliquae plant ${ }^{-1}$. Main stem length was measured as the plant height. Numbers of siliquae plant ${ }^{-1}$ and seeds siliqua $^{-1}$ were counted from 30 randomly selected siliquae after hand threshing. The 
seed yield was measured by harvesting net plot area of each plot at crop full maturity (physiological maturity). After harvesting, the plants were left in the field for sun drying to their constant weight (12\% moisture content). Then, the total above ground plant weight after removal seed was computed (stover yield) by a precise scale $(0.001 \mathrm{~g})$ and expressed as $\mathrm{kg} \mathrm{ha}^{-1}$. Eight samples of 100 seeds were taken from each seed lot of the experimental units and they were weighed afterwards. Then, the average multiplied by 10 recorded as 1000-seed weight (TSW). Harvest index (HI) was calculated as ratio of seed yield to biological yield. The seed oil contents were determined with the Soxhlet apparatus at the laboratory of university.

Oil yield was computed by multiplying seed yield and oil content.

\section{Statistical analysis}

The data was analysed statistically according to Factorial Randomized Block design. The significance of the overall differences among the treatments was determined by using the ' $F$ ' test. Conclusion was drawn at 5 per cent probability level. When ' $F$ ' value in the analysis of variance table was found to be significant, the critical difference (CD) was computed to test the significance of the difference between two treatment means (Fisher and Yates, 1963).

\section{Results and Discussion}

\section{Effect of nitrogen}

Application of nitrogen increased all the yield contributing characters viz., length of siliqua. Number of seed siliqua ${ }^{-1}$, 1000-seed weight significantly upto $160 \mathrm{~kg} \mathrm{ha}^{-1}$ of $\mathrm{N}$ except number of siliqua plant ${ }^{-1}$ significantly higher up to $120 \mathrm{~kg} \mathrm{ha}^{-1}$ of $\mathrm{N}$. Application of $40 \mathrm{~kg}$ $\mathrm{ha}^{-1}$ of $\mathrm{N}$ resulted in significantly higher all the yield contributing characters over the control $\left(0 \mathrm{~kg} \mathrm{ha}^{-1} \mathrm{~N}\right)$. This might be due to the fact that nitrogen application increased the root development which enhanced the absorption of nutrients from soil which resulted in better development of source capacity i.e. leaf area, which ultimately enhanced photosynthesis efficiency and its utilization towards yield contributing characters. Similar results have also been reported by several workers viz., Bhari et al., (2000), Bhaleroo et al., (2001), Tripathi and Tripathi (2003), Shelly and Virender (2010).

Nitrogen fertilization enhanced the stover yield with increase in the dose of nitrogen up to $160 \mathrm{~kg} \mathrm{ha}^{-1}$. This might be due to the fact that nitrogen application increased all the growth contributing characters viz. plant height $(\mathrm{cm})$, branches plant $^{-1}$ and leaf area index which enhanced the Stover production. The beneficial effect of nitrogen fertilization on stover yield of mustard has also been reported by Bhari et al., (2000), Bhaleroo et al., (2001).

The highest seed yield (16.44 $\left.\mathrm{q} \mathrm{ha}^{-1}\right)$ and least seed yield $\left(9.91 \mathrm{q} \mathrm{ha}^{-1}\right)$ were belonged to the plot which received $120 \mathrm{~kg} \mathrm{ha}^{-1} \mathrm{~N}$ and control $\left(0 \mathrm{~kg} \mathrm{ha}^{-1} \mathrm{~N}\right)$, respectively. The seed yield significantly increase with every increasing dose of nitrogen up to $120 \mathrm{~kg} \mathrm{~N}$ ha $^{-1}$. The highest yield of $16.44 \mathrm{q} \mathrm{ha}^{-1}$ was recorded with $120 \mathrm{~kg} \mathrm{~N} \mathrm{ha}^{-1}$ which remained at par with $160 \mathrm{~kg} \mathrm{~N} \mathrm{ha}^{-1}\left(16.41 \mathrm{q} \mathrm{ha}^{-1}\right)$. The increase seed yield was associated with increase in all yield contributing characters viz. siliquae plant $^{-1}$, length of siliqua, seed siliqua ${ }^{-1}$, and test weight. Adequate supply of nitrogen facilitated better growth and development of crop plant, enhanced nutrient content and resulted significant increase in yield attributes. Similar results have also been reported by Butter and Aulakh (1989), verma et al., (2014) (Table 2).

Nitrogen application resulted in significant increase in protein content with progressive 
increase in the dose of nitrogen. The higher protein content of $24.54 \%$ was obtained with $120 \mathrm{~kg} \mathrm{~N}^{-1}$ which remained at par with 160 $\mathrm{kg} \mathrm{N} \mathrm{ha}{ }^{-1}(24.43 \%)$. The increase in protein content was mainly due to the increase in nitrogen uptake by the crop. It may be stated that due to higher availability of nitrogen in plants, the synthesized carbohydrates may be converted more rapidly in to proteins which in turn enhanced the protein content of seed. Kachroo and Kumar (1999), Kumar et al., (2001) and singh (2002) have also been reported the increase in protein content with increasing doses of nitrogen. Seed oil content was significantly affected by different nitrogen levels and varieties. The maximum oil content (39.45\%) was reported at under control $\left(0 \quad \mathrm{~kg} \mathrm{ha}^{-1} \mathrm{~N}\right)$, then significantly decreased with increase doses of nitrogen rates. The resulting confirmed the finding of earlier researcher's Chuma et al., (2001), Saleem et al., (2001), who pointed out that oil content decrease with the increasing rate of nitrogen. The increase in oil yield was mainly due to increase in seed yield with increasing doses of nitrogen was also reported byDeekshitula et al., (2001), Singh (2002), pandey et al., (2015).

\section{Effect of varieties}

Difference among varieties contributed to a great extent in influencing the seed yield of Indian mustard on account of its effect on the attributes, yield and quality and of the plant at various stages. The various growth and yield parameters affected significantly, due to various mustard varieties. Variation among different varieties for different growth and yield attributes culminated in to inconspicuous differences in seed yield in spite of the fact that genotypes differed significantly for stover yield (and also biomass yield).

The seed yield of mustard depends mainly on the number of siliquae plant ${ }^{-1}$ length of siliqua. Number of seed siliqua ${ }^{-1}, 1000$-seed weight as these characters have high degree of positive correlation with seed yiel. Variety NDR-8501 has higher values of all the above mentioned yield contributing characters followed by Vardan and Maya. It may be the main reason for better yield of NDR-8501, which was significantly higher over other varieties. There was significant difference in protein content and oil yield of varieties (Fig. 1 and 2).

Table.1 Physical and chemical properties of soil of the experimental field at the beginning of the study (2015-16)

\begin{tabular}{|l|l|l|}
\hline S.No. & Particulars & Values \\
\hline (i) & Sand $(\%)$ & 25.0 \\
\hline (II) & Silt $(\%)$ & 49.50 \\
\hline (III) & Clay $(\%)$ & 25.50 \\
\hline (IV) & Textural class & Silt loam \\
\hline (I) & pH $(1: 1.25$ soil $:$ water $)$ & 8.2 \\
\hline (II) & Organic carbon $(\%)$ & 0.32 \\
\hline (III) & EC dSm ${ }^{-1}$ at $25{ }^{0} \mathrm{C}$ & 0.24 \\
\hline (IV) & Available $\mathrm{N}\left(\mathrm{kgha}^{-1}\right)$ & 136.5 \\
\hline (V) & Available $\mathrm{P}_{2} \mathrm{O}_{5}\left(\mathrm{~kg} \mathrm{ha}^{-1}\right)$ & 14.5 \\
\hline (VI) & Available $\mathrm{K}_{2} \mathrm{O}\left(\mathrm{kgha}^{-1}\right)$ & 248.5 \\
\hline (VIII) & Available $\mathrm{Zn}\left(\mathrm{ppm}^{-1}\right.$ & 0.54 \\
\hline
\end{tabular}


Int.J.Curr.Microbiol.App.Sci (2018) 7(7): 3152-3161

Table.2 Effect of nitrogen levels on yield attributed and yield of mustard (Brassica juncea Curzen and Cross.) varieties under late sown condition

\begin{tabular}{|c|c|c|c|c|c|c|c|}
\hline $\begin{array}{l}\text { Treatment } \\
\text { Siliqua } \\
\text { plant }^{-1} \\
\end{array}$ & $\begin{array}{l}\text { No. of } \\
\text { siliqua }\end{array}$ & $\begin{array}{c}\text { Length of } \\
\text { siliqua }^{-1} \\
\text { (cm) }\end{array}$ & $\begin{array}{c}\text { No. of seed } \\
\text { weight }\end{array}$ & Test & $\begin{array}{c}\text { Seed } \\
\text { yield } \\
\left(\mathbf{q} \mathbf{h a}^{-1}\right) \\
\end{array}$ & $\begin{array}{c}\text { Stover } \\
\text { yield } \\
\left(\mathrm{q} \mathrm{ha}^{-1}\right) \\
\end{array}$ & $\begin{array}{c}\text { Harvest } \\
\text { index } \\
(\%) \\
\end{array}$ \\
\hline \multicolumn{8}{|c|}{ Nitrogen levels $\left(\mathrm{kg} \mathrm{ha}^{-1}\right)$} \\
\hline$\overline{\mathbf{0}}$ & 133.6 & 4.25 & 8.59 & 4.36 & 9.91 & 43.57 & 18.53 \\
\hline 40 & 156.8 & 4.75 & 10.80 & 4.51 & 1.36 & 48.70 & 18.91 \\
\hline 80 & 190.7 & 5.36 & 12.27 & 4.52 & 3.70 & 54.25 & 20.16 \\
\hline 120 & 279.4 & 6.11 & 13.74 & 4.26 & 16.44 & 59.14 & 21.75 \\
\hline 160 & 264.0 & 6.18 & 14.26 & 4.56 & 16.41 & 60.46 & 21.34 \\
\hline SEm \pm & 6.8 & 40.15 & 0.44 & 0.08 & 0.41 & 1.38 & \\
\hline CD & 19.8 & 20.4 & 41.27 & NS & 1.19 & 3.99 & \\
\hline \multicolumn{8}{|l|}{ Varieties } \\
\hline$\overline{\text { Vardan }}$ & 198.6 & 5.22 & 11.65 & 4.50 & 13.53 & 51.11 & 20.93 \\
\hline NDR-8501 & 219.5 & 5.60 & 12.80 & 4.44 & 14.25 & 56.53 & 20.13 \\
\hline Maya & 196.6 & 5.18 & 11.30 & 4.46 & 12.91 & 50.84 & 20.25 \\
\hline SEm \pm & 5.50 & 0.1 & 20.3 & 40.0 & 10.32 & 1.07 & \\
\hline CD & 15.3 & 50.3 & 40.98 & 0.03 & 0.92 & 3.09 & \\
\hline
\end{tabular}


Table.3 Effect of nitrogen levels on protein content, nitrogen content, oil content and oil yield of mustard (Brassica juncea Curzen and Cross.) varieties under late sown condition

\begin{tabular}{|c|c|c|c|c|c|}
\hline \multirow[t]{2}{*}{ Treatment } & \multirow{2}{*}{$\begin{array}{l}\text { Protein } \\
\text { content } \\
(\%)\end{array}$} & \multirow[t]{2}{*}{$\begin{array}{l}\text { Oil content } \\
(\%)\end{array}$} & \multirow[t]{2}{*}{$\begin{array}{l}\text { Oil yield } \\
\left(\mathrm{q} \mathrm{ha} \mathrm{ha}^{-1}\right)\end{array}$} & \multicolumn{2}{|c|}{$\begin{array}{l}\text { Nitrogen } \\
\text { Content }(\mathrm{cm})\end{array}$} \\
\hline & & & & Seed & Stover \\
\hline \multicolumn{6}{|c|}{ Nitrogen Levels $\left(\mathrm{kg} \mathrm{ha}^{-1}\right)$} \\
\hline 0 & 19.13 & 39.45 & 3.91 & 3.06 & 0.49 \\
\hline 40 & 21.60 & 38.86 & 4.41 & 3.45 & 0.62 \\
\hline 80 & 22.95 & 37.92 & 5.19 & 3.67 & 0.74 \\
\hline 120 & 24.30 & 37.36 & 6.14 & 3.88 & 0.91 \\
\hline 160 & 24.53 & 36.54 & 5.99 & 3.92 & 0.98 \\
\hline SEm \pm & 0.54 & 0.37 & 0.18 & 0.04 & 0.04 \\
\hline $\mathrm{CD}(\mathrm{P}=0.05)$ & 1.57 & 1.36 & 0.64 & 0.11 & 0.11 \\
\hline \multicolumn{6}{|l|}{ Varieties } \\
\hline Vardan & 22.21 & 38.01 & 5.14 & 3.55 & 0.73 \\
\hline Narendra Rai-8501 & 22.65 & 38.03 & 5.41 & 3.62 & 0.82 \\
\hline Maya & 21.11 & 38.05 & 4.91 & 3.37 & 0.70 \\
\hline SEm \pm & 0.42 & 0.44 & 0.30 & 0.03 & 0.03 \\
\hline $\mathrm{CD}(\mathrm{P}=0.05)$ & 1.22 & NS & 0.88 & 0.09 & 0.08 \\
\hline
\end{tabular}


Fig.1 Seed yield, Stover yield ( $\mathrm{q} \mathrm{ha}^{-1}$ ) and harvest index (\%) of mustard influenced by nitrogen levels and varieties

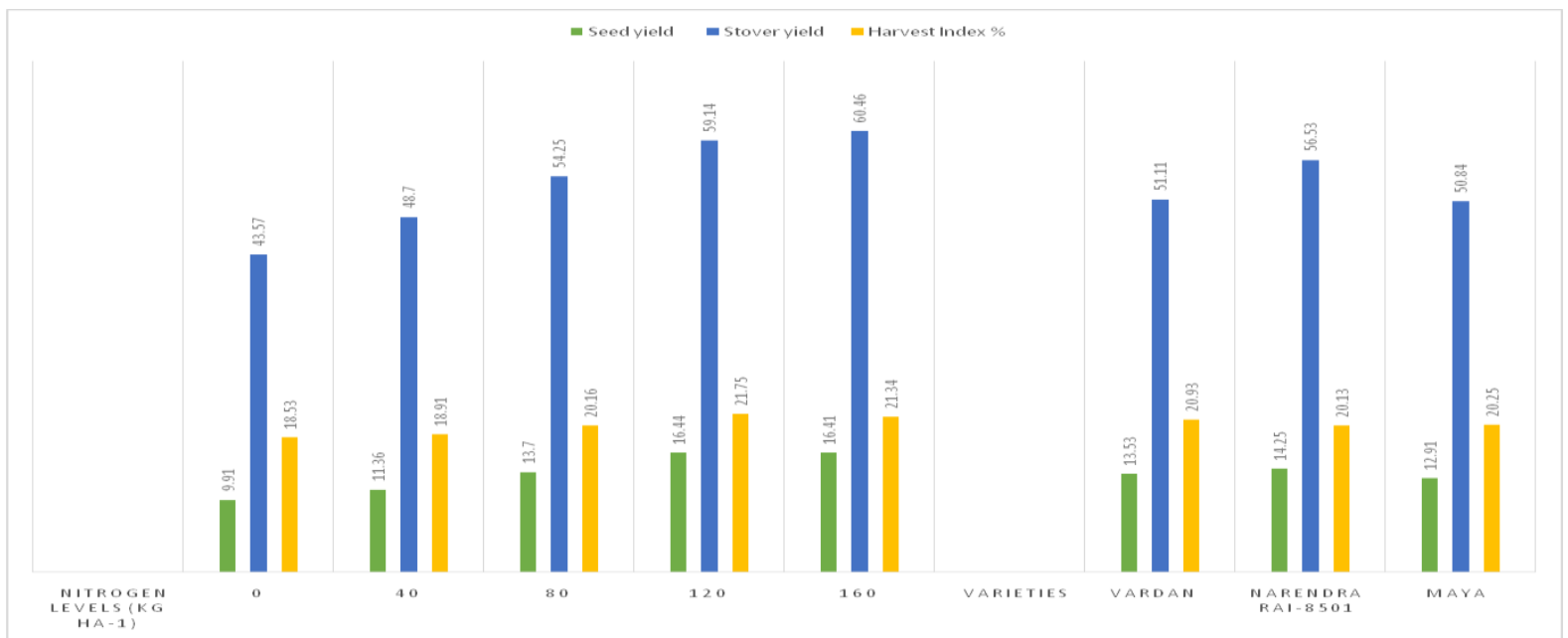

Fig.2 Protein content, oil content and oil yield in seed of mustard influenced by nitrogen levels and varieties

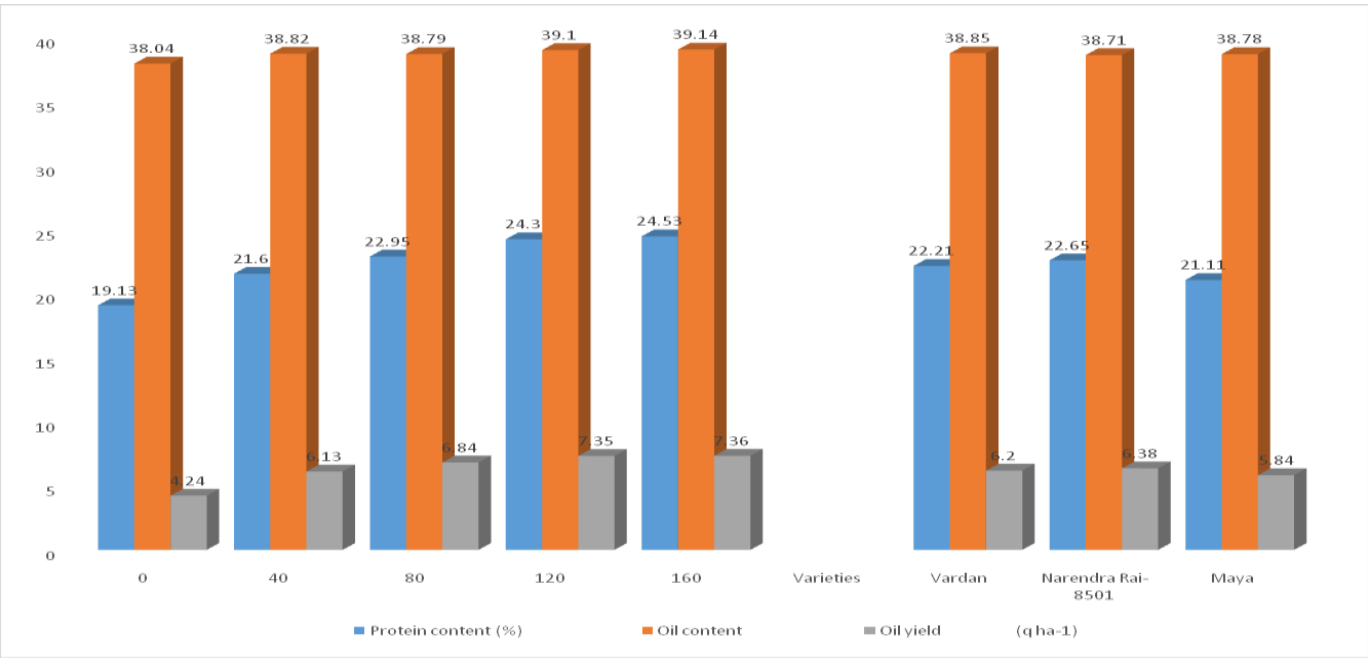


Variety NDR-8501 recorded highest protein content $(24.53 \%)$ and oil yield (7.35 $\left.\mathrm{qha}^{-1}\right)$ followed by Vardan and Maya, which may be due to little variation in genetic characters of the varieties (Table 3).

\section{Economics}

The variations in cost of cultivation were recorded due to different nitrogen levels. Increasing levels of nitrogen increased the cost of cultivation as being major monetary inputs.

On the other hand, major variation in gross return, net return and benefit cost: (Rs. 2.67 $\mathrm{Re}^{1}$ invested) were observed due to variation of yield and cost cultivation. Maximum cost of cultivation as well gross return were recorded at highest level of nitrogen $(160 \mathrm{~kg}$ $\mathrm{ha}^{-1}$ ) with Variety NDR-8501 followed by $120 \mathrm{~kg} \mathrm{ha}{ }^{1}$ with same variety.

In conclusion, a nitrogen level of $120 \mathrm{~kg} / \mathrm{ha}$ can be considered as suitable dose for higher yield of mustard. Among mustard varieties, NDR-8501 performed most promising followed by vardan and maya in terms of growth and yield and can be recommended for the cultivation in eastern UP.A combination of mustard variety NDR-8501 along with $120 \mathrm{~kg} N$ ha-1 recorded significantly higher growing yield over rest of the treatments. Likewise net returns and benefits cost ratio was also found substantly higher with the combination. However further experimentation is required for making the conformation of results.

\section{References}

Bani-saeedi, A., 2001. Examination of different amount of nitrogen and density on growth, quantity and quality characters in canola, in Khozestan climate condition. M.Sc. Thesis, Dezfool University, Dezfool, Iran.
Bhalerao, P.D. 2001. Effect of irrigation and nitrogen on Indian mustard (Brassica juncea) Varieties in Vidharbha region. Indian J. Agron., 46: 727-731.

Bhari, N.R., R.K. Singh and P.S. Mann. 2000. Response of Indian mustard (Brassica juncea) to nitrogen and phosphorus on Tonipramments of North western Rajsthan. Indian J. Agron., 45: 746-757.

Chamoro, A.M., L.N. Tamagno, R. Bezus and J. Sarandon. 2002. Nitrogen accumulation, partitioning and nitrogen use efficiency in canola under different nitrogen availabilities. Comm Soil Sci Pl Anal., 33: 493-504.

Cheema, M.A., M. Saleem and M.A. Malik. 2001. Effect of row spacing and nitrogen management of agronomic traits and oil quality of canola (Brassica napus L.). Pak. J. Agri. Sci. 38: 15-18.

Deekshitulu, V.V.R., G. Subbaiah, R.V.R. Viah and M. Singh. 1998. Effect of nitrogen and sulphur on seed yield, oil content and oil yield of Indian mustard. $J$ Oilseeds Res., 15: 355-56.

Dubey, O.P., T.R. Sahu and D.C. Garg. 1994. Response and economics in relation to nitrogen and sulphur nutrition in Indian mustard (Brassica juncea). Indian $J$ Agron., 39: 49-53.

Grami, B. and L.J. La Croix. 1977. Cultivar variation in total nitrogen uptake in rape. Canadian J Pl Sci.,57: 619-24.

Kachroo, D. and A. Kumar. 1999. Seed weight, oil and protein contents of Indian mustard (Brassica juncea) as influenced by nitrogen and sulphur fertilization. Ann Agric Res., 20: 369-71.

Kumar, A., D.P. Singh, B. Singh and Yashpal. 2001. Effect of nitrogen application on partitioning of biomass, seed yield and harvest index in contrasting genotypes of oilseed Brassicas. Indian J Agron., 46: 162-67.

Laine, P., A. Ourry, J. Macduff, J. Boucaud and J. Salette. 1993. Kinetic parameters of nitrate uptake by different catch crop species-effects of low temperatures or previous nitrate starvation. Physiol Pl., 88: 85-92.

Malagoli, P., P. Laine, L. Rossato and A. 
Ourry.2005. Dynamics of nitrogen uptake and mobilization in field grown winter oilseed rape (Brassica napus) from stem extension to harvest. Ann Bot., 95: 85361.

Pandey, N., S. Kumar, and G. Singh. 2015. Effect of planting geometry on growth and yield of mustard varieties. International Journal of Farm Sciences, 5: 47-52.

Reddy, G.H.S. and T.Y. Reddy. 1998. Principles of Agronomy: Irrigation requirement of primary crops. In efficient use of irrigation water. Kalyani publishers. Ludhiana $\mathrm{p} 238$.

Saleem, M., M.A. Cheema and M.A. Malik, 2001. Agro economic assessment of canola planted under different levels of nitrogen and row spacing. Int. J. Agric. Biol. 3: 2730.

Shelly, N. and S. Virender. 2010. Growth productivity and quality of canola and non-canola cultivars of oilseed rape (Brassica napus) as influenced by time of application of sulphur. J. Oilseeds Res., 23: 123-127.

Siadat, S.A., O. Sadeghipour and A.H. Hashemidezfouli. 2010. Effect of nitrogen and plant density on yield and yield component of Rapeseed. J. Crop Prod. Res. 2: 49-62.

Singh, A.K., S.N. Singh, O.P. Singh, M.A. Khan. 2008. Quality of Indian mustard (Brassica juncea L.) as affected by nitrogen and sulphur fertilizers in a nutrient deficient soil. Indian J AgricBiochem., 21: 39-41.
Singh, S.P. and V. Singh. 2005. Effect of nitrogen, sulphur and zinc on Indian mustard (Brassica juncea). Indian J Agric Sci., 75: 828-30.

Singh, P.C. 2002. Effect of different levels of nitrogen and phosphorus on yield, yield components and oil content of mustard (Brassica juncea). J of living world, 9:14.

Singh, Y., T. Singh, U.N. Singh and P.K. Rajput. 2010. Effect of nutrient management on yield, quality and economics of irrigated Indian mustard (Brassica juncea). Indian J Agric Sci., 80: 691-94.

Tripathi, A.K. and H.N. Tripathi. 2003. Influence of nitrogen levels on growth, yield and quality of Indian mustard (Brassica juncea) cultivar.Varuna. Farm Sci. J., 12:71-72.

Yau, S.K. and N. Thurling. 1987a. Genetic variation in nitrogen uptake and utilization in spring rape (Brassica napus) and its exploitation thorough selection. Plant Breed., 98: 330-38.

Yau, S.K. and N. Thurling. 1987b. Variation in nitrogen response among spring rape (Brassica napus) cultivars and relationship to nitrogen uptake and utilization. Field Crops Res., 16: 139-55.

Zhao, F.J., E.J. Evans, P.E. Bilsbrrow and J.K. Syers. 1993. Influence of sulphur and nitrogen on seed yield and quality of low glucosinolate oilseed rape (Brassica napus L.). J Sci Fd Agric., 63: 29-37.

\section{How to cite this article:}

Nikhil Raghuvanshi, Vikash Kumar and Jai Dev. 2018. Study on Nitrogen Levels and Varieties on Yield Contributing Characters, Quality and Economics of Mustard (Brassica junceaCurzen and Cross.) Varieties under Late Sown Condition. Int.J.Curr.Microbiol.App.Sci. 7(07): 31523161. doi: https://doi.org/10.20546/ijcmas.2018.707.368 